\title{
Liuqin Drama's Origin and Early Development
}

\author{
Zhibo Wang, MA \\ Foreign Language School \\ of Linyi University, Shandong Province, P.R. China
}

doi: 10.19044/esj.2016.v12n26p211 URL:http://dx.doi.org/10.19044/esj.2016.v12n26p211

\begin{abstract}
Liuqin Drama did not have a long history. It started from Qing Dynasty. It did not have a glorious background. It actually started from begging. Yet its singing is marvelous. Its early name was "Lahun" Tune, which literally meant "soul-pulling" Tune in Chinese. Its attraction is enormous, and with generations of accumulation of artistic culture, it has become one of the major genres of folk drama of Southern Shandong, Northern Jiangsu and Northeastern Anhui Province. This paper introduces the beginning and the later development of the Liuqin Drama.
\end{abstract}

Keywords: Liuqin, Sanxian, Lahun Tune, branches, spreading

\section{Introduction}

Liuqin Drama is a traditional folk drama popular in South Shandong Province, northeastern Anhui Province and north Jiangsu Province. It has been liked by the people of theses areas, especially the farmers here. They like it because Liuqin Drama is not far from them. Many of the ordinary farmers here can sing some lines of Liuqin Drama. Therefore, the early development period of this genre is a history of spreading and enrichment. When Liuqin Drama is studied, people should not forget the routes of singing and begging and the Liuqin Drama's styles borrowed from other theatrical genres, and the generations of famous singers. This paper describes both of these factors of early Liuqin Drama and discusses how these factors joined together to form the Liuqin Drama we watch today.

\section{The Origin of Liuqin Drama: Lahun Tune}

Liuqin Drama was originally named "Lahun" Tune. "Lahun" means "soul-pulling" in Chinese. It was so named because the tunes used in this drama draw very long at the end, which add to the beauty of the singings of this drama.

The Liuqin Drama was started around the Qing Dynasty. In areas of the southern Linyi, the residents were mostly peasants. Because the output of 
this land was often not enough to feed the people, begging was commonplace. In fact, begging became a custom. By and by they found that adding singing to the calls of the doors had better results, and that was the beginning of Lahun Drama. of Linyi:

This decision on the origin of Liuqin Drama is proved by the Record

This area (Linyi area) is a place surrounded by water. There are nine years of flooding in ten years time. The people wandered around to beg for food and by and by this became a custom. At first the begging was a result of hunger and later it became a thing everybody did. They took their family, carried their baggage, and invited friends and named this behavior as as an escape from bad harvest, and did not regard this as strange. (qtd in Zhang et al 5)

It is often said by the old Lahun artists, "Lahun Tune is beggers' Tune", which from another perspective proved that the origin of Liuqin Drama comes from begging (Zhang et al 6).

Lahun Drama was first series of singing, sometimes with the simple accompaniment of a small gong, a small bell, or bamboo clappers. The words were sometimes said rather than sung. Gradually, the attraction of the singing grew and then there were people who specialized in the singing and the singers were no longer limited to beggars. In this way the Lahun Drama came into being.

\section{Liuqin Drama's Early Branches and Specializations}

Lahun Drama has various branches. One branch is in the southern Shandong Province, mainly including Tancheng County. Another branch is in northern Jiangsu Province, such as Xinyi and Xuzhou areas. The last branch is in western Shandong Province, including Tengzhou County, Zaozhuang City, and eastern Anhui province, such as Sizhou County. The branch of Shandong province and Jiangsu province was named Liuqin Drama by the major musical instrument the "Liuye" instrument, which literally means "Willow Leaf" instrument in the 1950's. The branch of northeastern Jiangsu province was named Huaihai drama. But the Anhui branch was named Sizhou drama because "Sizhou" was the name of the place where the drama was popular.

In the development of Liuqin Drama, it learned from other local singings too. "Lahun singing mainly comes from Zhouguzi, Liuzi Drama, Huagu and folk singing"(Zhang et al 6). Zhouguzi can be literally translated into English as "drums on the elbow", which seems not likely an art form but a superstitious vocation. Zhouguzi "was based on the popular folk flower drum, which gradually changed into an folk opera with its central tune being 'tunes of the girls' "( Kong 5). In the past, in Linyi and its south, the northern 
Jiangsu province, people often asked religious masters to drive away the demons around themselves or their houses. The folk artists carried out such activities too. They used single sided drums with nine rings. Because of the activity's importance, the ceremony could be quite grand: tables were set and offerings must include fish and meat. Drawings of ancestors and of the ninth son of Wei Zheng (a god of justice) were put up and then the rituals were started. Where there was a need, there was supply, so Zhouguzi prospered. Zhouguzi is also called girls" tunes. From the existing songs of "greeting the god", "settling down the god" and "seeing the god leave", it is quite obvious that Zhouguzi came from superstitious rituals (Zhang et al 8). Just because Zhouguzi's connection with superstitious rituals, many Liuqin singers deny they were in any way related to Zhouguzi (Kong 26).

Another origin was Liuzi Drama. Liuzi Drama is an ancient folk drama of Linyi area. It began to prosper in Linyi area since Qing Dynasty. Its major accompaniments are the "big three strings" so the local people called it "Xianzi" drama, meaning "string drama" in Chinese. In later chapters, the paper will discuss the tunes that Liuqin Drama borrowed from Liuzi Drama, which were many. Also similar to Liuzi Drama are the many plays that Liuqin Drama has, for instance, "Ganjiao" (Work As a Carrier), "Ronghua Story" (the Story of the flossy Flower), "Jinsuoji" (the Story of the Gold Lock) and so on (Zhang et al 13). Also, the major accompaniment of Liuzi Drama was the "three string" instrument, which was similar to what is used in Lahun Tune.

"Huagu" was another origin of Liuqin Drama. "Huagu" in Chinese means "stylistic drum". "Huagu" was played in a large area which included Linyi area, but the "Huagu" in Linyi is very unique, where it bore resemblance to Liuqin Drama.

Folk songs were the last origin of Liuqin Drama. Because Liuqin Drama originated in areas where people also learn or sung other folk songs, it is quite possible that Liuqin Drama was influenced by the tunes of the local people.

\section{The Early Development of Liuqin Drama}

It was already said in the previous section that Liuqin Drama came from the singing of the beggars. To solicit more food or money, the beggars sang what people liked to hear, and the tunes they used can be as varied as possible. Years and years passed by and the tunes these people sung became mixed and a new kind of drama came into being. Also the plots of the stories they portrayed were purified and different plays were created. The content of the dramas was enriched too, and the Liuqin artists stopped begging door by door and began to perform in marketplaces, and then they went into theatres. Also different from the past when only one person sung, more people were 
involved in the playing, hence different characters appeared. In the beginning, there were only two or three characters in a play. Limited by the sizes of the troupes, one actor had to play several characters in a play, and the "Momaozi" drama came into being where actors may change their roles by shifting their caps, "Momaozi" meaning "shifting the caps" in Chinese(Zhang et al 19). In fact in early Liuqin Drama, caps, towels, silk strips or so could all be used to represent different roles of one actor.

Like previously mentioned, the early singers of Liuqin Drama were mostly beggars, and were not professional actors. Then in the late $19^{\text {th }}$ century, many professional singers appeared. Sometimes when these actors ran into each other, they might put on a joint performance though this was quite rare at the beginning. As the Liuqin Drama developed, teams of actors appeared. Actors played in teams so that they could put on more complex dramas. These team performers appeared since 1900 till the new China was established. The means of playing was no longer "Momaozi" drama. Set actors for certain characters were established. More important was the change of lines, which began to be set rather than improvised. After these changes, actors gathered together and troupes were established. So Liuqin Drama became like other kinds of dramas. Once before the Cultural Revolution, the Liuqin troupes of Linyi included more than 100 people. Later, Linyi Art School was founded to train more actors of Liuqin Drama. Now the major actors of Linyi Liuqin Drama Troupe almost all came from Linyi Art School.

\section{Features of Early Liuqin Drama}

At the very beginning of Liuqin Drama's history, actors often used the "dasanxian" (meaning three big strings) (Zhang et al 23). Some of the old major Liuqin singers still alive remember that when they were little, they saw their parents or grandparents took the "dasanxian" when they went out to sing. But the "dasanxian" was too big and heavy, so actors worked with carpenters and created a new instrument which was similar to the "sanxian" and the "yueqin" but was considerably smaller and thus easier to carry, and that was the early liuqin. It was said that the wood used to make the first liuqin was the sunny side of the bottom part of the stem of a willow tree. At the beginning, the "liuqin" was still very big, with a long neck, on which there were seven struts. Because this kind of "liuqin" was still inconvenient to handle and play, a similar but smaller instrument was made, and this was the beginning of the real "liuqin". The "liuqin" is very necessary for Liuqin Drama because it at least satisfies the basic need of the music of Liuqin Drama, the rhythm. Therefore almost all liuqin performers knew how to play this instrument. In the past, the liuqin became almost all musical accompaniment of a singer or a troupe. However, as the time went by, on the basis of communication among 
folk dramas, other instruments were introduced into Liuqin Drama, including the sheng, the flute, the yangqin and the pipa.

With the new folk instruments, the Liuqin Drama became more expressive. Moreover, western instruments were also brought into Liuqin, including orchestral instruments. That happened in the 1950's and 60's. Another important feature of early Liuqin Drama was that it was sung or spoke but not written, and the singing, the words and the music were not set. So each person sang his or her own Liuqin. In the old days, Lahun Tune was also called "Yixin" tune, which means that the singers could sing to their hearts' content (Kong 4). This feature was good because it provided more variety. However, it was not beneficial for the development of Liuqin Drama because if one singer left or died, nothing was left to be inherited. This situation was changed in the 1950's when music scores were introduced into Liuqin Drama and new singers can inherit from the old ones, and different singers can learn from each other without even seeing each other.

All these changes enabled the old Liuqin Drama to catch up with the times and became the favorite of multitudes today.

Aside from the playing of the liuqin, there were other accompaniments too. In the early times, the bangzi was used for the rhythm. The bangzi was a simple instrument the use of which was to strike one piece of hard wood against another. Although the sound was monotonous and simple, it provided a good start for the plays of Liuqin Drama. Then other simple percussion instruments were brought in. The player of the liuqin also played other percussion instruments. He was pretty busy but that suits well the early Liuqin Drama. Big gongs and small gongs were first used after the liuqin. Then, with the gathering of more people in the troupe, the big drums, the small drums and the ba were used thus giving Liuqin Drama enriched musical characteristics. The percussion music of Liuqin Drama developed with the help of generations of Liuqin players and finally it reaches the state which we see in today's theatre.

One last thing we need to mention is the influence of Peking Opera upon Liuqin Drama. There was once a troupe in Tancheng County which played both Lahun Tune and Peking Opera. Then they mixed the two genres and enriched the music of Lahun Tune.

Therefore, the percussion music of Lahun Tune was originated from Linyi, and partly from Peking Opera and then was spread to the southern Shandong Province, northern Jiangsu Province, Anhui Province and so on.

\section{The Roles of Early Liuqin Drama}

In the early days of Liuqin Drama, the singing was mostly impromptu. The development of the roles of Liuqin Drama experienced a long process. 
At first, the troupe was very small, so one actor had to play several different roles. To tell the different roles of one actor, he or she wore different caps. And the changing of caps showed the changing of different roles.

Also, there were talking plays and fighting plays. In the talking plays, the main ideas were showed by talking and singing. The fighting plays involved actions. At first the actions of Liuqin Drama were very plain, and through the help of Peking Opera, Liuqin Drama, beginning with simple simulation of actions, had its own rich set of action.

At the very beginning, there were only two roles, namely "Xiaosheng" and "Xiaodan". "Xiaosheng" refers to good looking young man and "Xiaodan", good looking young woman. Even after the different roles were introduced, one actor still needed to play several of these roles. When different roles such as "Sheng, Dan, Jun, Chou, Old Positive Young Man and White Face" were developed, Liuqin established its own roles. "Old Man" and "Three Sideburns" were called "Big Men" roles. They seldom played major roles but they were important. "Colorful Young Women" who also played other roles were called "Laoguai", which meant "Old Turn". The major young woman's role was called "Small Head", and those who could play this role and "Dark Costume" were called "Erjiaoliangzi". The role of "Dark Costume" came from Peking Opera, referring to old women's role. "Erdaoliangzi" in Chinese language literally meant one actor playing two roles.

Also old men's and women's roles were called "Laoertou", which literally meant the two old roles. The clown is called "Goujiao", the literal meaning of which is now hard to trace. The clowns were very much liked by the audience, because he was funny and witty in the dialogues.

The acting of Liuqin Drama was very simple at first, and from Peking Opera, Liuqin Drama obtained its acting. Even today, you can think of Peking Opera when you see the acting of Liuqin Drama, such as "Preening" "Pulling the shoes" and so on and so forth.

Liuqin develops from simple folk dramas, and so it has very typical folk features. It is very good when it showed the ordinary people's life. But as it has very short history, it is not very good at showing abstract plays, especially the court plays.

The makeup of actors also experiences a feature of development. At the very beginning, the actors could not afford costumes and makeups. Some of them went on stage with old cotton padded jackets. Later, small troupes came into being but actors still could not afford complicated costumes, and they went on stage in their usual clothes. It was a long time before the roles of young men wore colored balls on their caps and other simple costumes. In the history of Liuqin Drama, one stage needed to be mentioned, and that was the introduction of the costumes of Peking Opera. One of the troupes often played both Liuqin Dramas and Peking Operas and they used the costumes of Peking 
Opera for the playing of Liuqin Drama thus improved the costumes of Liuqin Drama.

\section{The Spreading of Liuqin Drama}

Liuqin Drama did not experience a full bloom and then spread to outside Linyi area (Zhang et al 31). The history of Liuqin Drama was one carried all over in parts of Shandong, Jiangsu and Anhui provinces at the very beginning. Begging was the most powerful medium by which Liuqin Drama spread out, and many of Liuqin Drama's features showed strong influence by this phenomena.

Lahun Tune originated in the Linyi area and it spread to the south to northern Jiangsu Province and northeastern Anhui Province. The reason for this was that the southern Linyi area was very poor. The northerner people went, the poorer they found the place to be. So they moved to the south. Although the northern Jiangsu province was poor too but much better than Linyi area.

Also causing the Lahun Tune to go south was the superstitious activities of northern Jiangsu Province. The people in northern Jiangsu Province was superstitious, and they sometimes would like to invite Lahun Tune actors to go there and help them to pray and if the prayers were successful, they would let the Lahun Tune actors to play again to thank the good deeds of the gods. They also invited Lahun Tune actors to open the locks when the keys were missing. They too would ask Lahun Tune actors to give them advices when they built their own houses. All in all, there was much to do for the Lahun Tune players.

Another reason why Lahun Tune actors went south was the language they spoke. The dialect of southern Linyi was very close to that of northern Jiangsu Province and northeastern Anhui Province, so the actors had no problem in communicating with the local people and the people in the area could understand the language of the drama both theatrically and linguistically.

There was another reason why Lahun Tune players went south and that was the fact that the government of Linyi did not quite approve of this genre. The county government of Linyi regarded Lahun Tune as corruptive. They decided that Lahun Tune was sexual and playing it was very close to prostitution, and so must be prohibited (Zhang et al 34).

Also, because the singing of Lahun Tune was beautiful, many women were attracted to it. So the patriarchs were against it too. Therefore the Lahun Tune players were driven from one place to another. In the southern areas, the people did not have such prejudice and so Lahun Tune could have some space of survival. 
There are many legends on how Lahun Tune originated. In these legends, stories of great singers were described. However, Lahun Tune did not originate from one or two players. It was a product of generations of singers. Of course, in this process, some great players made contributions.

Historically, the Tancheng County of Linyi area had the custom of going out and begging and this county was also famous for its Lahun Tune. So there were many great Lahun Tune actors who came from Tancheng County.

To locate the branches of Liuqin Drama's spreading more finely, the spreading of Lahun Tune went from Tancheng County to three directions. Lahun Tune first spread to northern Jiangsu Province, including Xinanzhen, Pixian and Haizhou. The branch which went to Haizhou, because of the different dialect and the influence from other dramas, evolved to "Huaihai" drama, (Huahai literally means the area between Huahe River and the coast). This was the east branch of Lahun Tune.

Lahun Tune went to the southwest and reached Siyang of Jiangsu Province and west to Sizhou, Lingbi, Suxian and then Bengbu and Yuxian. This branch was called the southern branch, and it was also named "Sizhou" drama.

There is a famous story about the spreading of Lahun Tune in the central branch from Yishui of Linyi area across Linyi and Cangshan to Yixian of Shandong Province and Xuzhou of Jiangsu Province. People said that the brothers of $\mathrm{Da} \mathrm{Wu}$ and Er Wu's singing were respectively called Da Wu's Elbow Drums (Zhou Gu Zi), and Er Wu's Elbow Drums. Very probably, they started with Elbow Drums, and when they went to Yixian, they changed to Lahun Tune. In the Elbow Drums, actors only hit the drums and there was no string accompaniment, and in Lahun Tune, actors only played string instrument and did not use drum. Da $\mathrm{Wu}$ and $\mathrm{Er} \mathrm{Wu}$ already used string instruments and that was why their singing was Lahun Tune instead of the Elbow Drums.

$\mathrm{Da} \mathrm{Wu}$ and $\mathrm{Er} \mathrm{Wu}$ were great masters not only in what they sang, but also in the fact that they taught a lot of pupils. Da Wu and Er Wu then did not get along and they split. Da Wu went to Pixian, Jiangsu Province and $\mathrm{Er} \mathrm{Wu}$ stayed in Yixian, Shandong Province. Er Wu had lots of pupils and some of them went to Xuzhou and that was how Lahun Tune was transmitted to Jiangsu Province.

Another important site of Lahun Tune was Tengxian County of Shandong Province. There were two different versions of how this branch was established. One version was that that branch was led by an actor named $\mathrm{Wu}$ Qingzhi, who learned Lahun Tune from Yixian County of Shandong Province. Another version was that the actor Li Wenxi, a beggar who begged in 
Tancheng County, learned the art and then he returned home and started to sing Lahun Tune. He then had many pupils and so Lahun Tune prospered.

After Lahun Tune spread to Tengxian County, many singers of other dramas began to sing Lahun Tune. Soon the art broke the limit of beggars. Many rich artistic young men began to like Lahun Tune. It was also said that there was a famous intellectual whose name was $\mathrm{Su}$, who taught Lahun Tune to his employees.

Then afterwards, Lahun Tune was transmitted from Tengxian County to Fengxian County, Peixian County, Xiaoxian County, and Dangshan County, and this branch was called the North Branch.

All in all, the spreading of Lahun Tune was a long process, and was done by generations of great singers. The three branches of Lahun Tune, influenced by their local people, built their own specific styles, which made this art form rich, diversified and colorful.

\section{Conclusion}

As mentioned previously, Liuqin Drama, bearing its early features, went south, southwest and southeast to different places and prospered. It should be stated that the life of early Liuqin Drama singers were not as colorful as most people nowadays think. They often had to go to new places and being outsiders made them vulnerable to bullies. The weather was not always favorable and if there were several days of rain, they might go hungry. Their vagrant life combined begging with singing and so made this theatrical genre seem somewhat contemptible. However, with the industriousness of early Liuqin Tune singers, which was typical in other Chinese folk arts, this genre flourished. That is why today's Liuqin Drama looks so beautiful and lovable to the audience.

\section{References:}

Zhang, Tiemin, et al. (2013): Liuqin Drama. Jinan: Shandong Friendship Press.

Kong, Peipei. (2007). "From Lahun air to Liuqin Drama". (doctoral dissertation)

Beijing: China Research Academy of Art. 